\title{
Shifting the perspective after the patient's response to an interpretation
}

\section{Peräkylä, Anssi}

2010

Peräkylä , A 2010 , ' Shifting the perspective after the patient's response to an interpretation '

, International Journal of Psychoanalysis , vol. 91 , no. 6 , pp. 1363-1384 . https://doi.org/10.1111/j.1745-8315.2010.

http://hdl.handle.net/10138/29482

https://doi.org/10.1111/j.1745-8315.2010.00323.x

publishedVersion

Downloaded from Helda, University of Helsinki institutional repository.

This is an electronic reprint of the original article.

This reprint may differ from the original in pagination and typographic detail.

Please cite the original version. 


\title{
Shifting the perspective after the patient's response to an interpretation
}

\author{
Anssi Peräkylä \\ Helsinki Collegium for Advanced Studies, PO Box 4, University of Helsinki, \\ 00014 Helsinki, Finland - anssi.perakyla@helsinki.fi
}

(Final version accepted 9 March 2010)

\begin{abstract}
Psychoanalytic interpretation is normally understood as a sequence of two utterances: the analyst gives an interpretation and the patient responds to it. This paper suggests that, in the interpretative sequence, there is also a third utterance where psychoanalytic work takes place. This third interpretative turn involves the analyst's action after the patient's response to the interpretation. Using conversation analysis as method in the examination of audio-recorded psychoanalytic sessions, the paper will explicate the psychoanalytic work that gets done in third interpretative turns. Through it, the analyst takes a stance towards the patient's understandings of the interpretation, which are shown in the patient's response to the interpretation. The third interpretative turns on one hand ratify and accept the patient's understandings, but, in addition to that, they also introduce a shift of perspective relative to them. In most cases, the shift of perspective is implicit but sometimes it is made explicit. The shifts of perspective bring to the foreground aspects or implications of the interpretation that were not incorporated in the patient's response. They recast the description of the patient's experience by showing new layers or more emotional intensity in it. The results are discussed in the light of Faimberg's concept of listening to listening and Schlesinger's concept of follow-up interpretation.
\end{abstract}

Keywords: conversation analysis, interpretation, listening, research

\section{Introduction}

Psychoanalytic interpretation is normally understood as a sequence of two utterances: the analyst gives an interpretation, and the client in one way or another responds to it. The importance of the patient's response to an interpretation has been recognized, emphasized and analysed in clinical and technical texts on psychoanalysis (see Casement, 2002, p. 8; Etchegoyen, 1999; Greenson, 1967, p. 41; Spence, 1982, p. 271) as well as in empirical research on psychoanalysis (Spence, 1995) and psychoanalytically oriented therapies (McCullogh et al., 1991; Schuller, Crits-Christoph and Connolly, 1991; Spence, Dahl and Jones, 1993). In this paper, I will suggest that, in the interpretative sequence, there is also a third utterance where psychoanalytic work takes place. This third utterance involves the analyst's action after the patient's response to the interpretation. The paper will explicate two basic types of this third interpretative turn and will discuss the psychoanalytical work they make possible.

While most psychoanalytic texts have not discussed the psychoanalytic work taking place after the patient's responses to interpretations, Faimberg's 
(1996) concept of listening to listening, as well as Schlesinger's (1995) concept of follow-up interpretation, offer theoretical insight into these phenomena. Both emphasize the importance of the analyst's attentiveness to the patient's response and his/her actions that follow that response.

Faimberg points out that: "[T]he interpretative cycle does not end with the analyst's interpretation" (1996, p. 667). Thus, what she calls interpretative cycle, involves "three logical phases of understanding" (ibid., p. 676). The first phase is the analyst's initial understanding, put into words in the interpretation. The second phase involves reattribution of meaning by the patient, arising from the patient's unconscious mental dynamics (history of his/her unconscious identifications). At this phase, the patient reinterprets what the analyst has said; this reinterpretation is betrayed by the patient's response to the interpretation (ibid., p. 668). Faimberg emphasizes the importance of the analyst's attentiveness to the patient's reinterpretations. Hence the term 'listening to listening': by listening to the patient's response, the analyst 'listens to listening'. The third phase of understanding arises from this: listening to listening entails comparison of the analyst's and the patient's understandings of the interpretation, which leads the analyst to assign retroactively a new meaning to what he/she said in the interpretation, beyond what he/she initially thought what he/she was saying. The retroactive meaning assignment can result in the analyst formulating a reinterpretation that takes into consideration the new meanings attributed to the initial interpretation by the patient (ibid., p. 676).

The processes of reinterpretation by the patient and the analysts referred to by Faimberg can take years (as illustrated in her extensive clinical vignette [1996, pp. 669-74]). The temporal scale of this paper is different as we will focus on sequences of single utterances. My temporal perspective is thus close to that of Schlesinger (1995), as, for him, what he calls the follow-up interpretations take place in "a very brief time-scale, closer to seconds and minutes than to hours and months" (p. 685). He emphasizes the importance of the analyst's alertness to what the patient says or does immediately after the delivery of the interpretation (pp. 664-5). The patient's immediate response to interpretation often involves "an ambiguous state reflecting both change and resistance to change" (p. 686). The analyst should be alert to this and, by means of follow-up interpretation, should interfere with the patient's efforts to repair the neurotic pattern. Through follow-up interpretation, the analyst can prolong the period of disturbance for the neurotic system.

The concepts proposed by Faimberg and Schlesinger have important ramifications that do not correspond to the phenomena that I present in this paper. For example, I will not discuss my findings in terms of unconscious identifications (which are central to Faimberg's theory) nor in terms of neurosis as a system (which is a key issue for Schlesinger). Bearing these important differences in mind, I however propose that my findings cast new light on some of the 'post-interpretation' phenomena that Faimberg and Schlesinger, each in their own terms, dealt with. The aim of this paper is to explicate the analysts' practices in attending to, and dealing with, the patients' responses to interpretation. The patients' responses to interpretations 
indicate the patients' understandings regarding the interpretations. The responses are followed by what I call the analysts' third interpretative turns, in which the analysts, while ratifying these understandings, shift the perspective of description. I will use the sociological research method of conversation analysis to show the interactional dynamics of these shifts of perspective. Thus I will offer detailed empirical description of moments of interaction in which and through which processes such as 'listening to listening' and to 'follow-up interpretation' take place.

\section{Data and method}

The data used in this paper come from a corpus of 58 audio-recorded psychoanalytic sessions, collected in 1999-2000 for the research project 'Psychoanalysis as social interaction' in Finland. The corpus involves two experienced analysts (IPA) and three patients with 20 consecutive sessions from each patient. All sessions have been transcribed. The data analysis took place in two stages. The first phase of analysis focussed on 27 randomly selected sessions from the corpus, from which 75 sequences involving interpretations were found. (Other interventions, such as confrontations and clarifications [Greenson, 1967, pp. 37-9] that are preparatory to interpretations, were excluded from the analysis.) The initial formulation of the structure of the interpretative trajectory and the interactional work of the third interpretive turn was arrived at this stage of the analysis. In the second phase of analysis, all instances of third interpretative turns were collected from the sessions that were not used in the first phase. This yielded 56 more instances of third interpretative turns. The conclusions made in the first phase of analysis were checked and (when needed) reformulated against these data.

It should be noted that most interpretations in our data are non-transference interpretations. This is reflected by the choice of extracts that are presented in this paper: only one out of five (Extract 3) involves a transference interpretation. In other extracts to be shown below, transference phenomena are most likely involved, for example, in the sense that the analyst serves as transference object for the patient. The analysis of such implicit transference, however, is beyond the scope of this paper. The relative frequency of non-transference interpretations in my data may be related to the style of these two analysts, to the specific character of these three dyads, or to the psychoanalytic culture in Finland - or it may be just accidental. In any case, there appears to be no reason why the findings related to third interpretative turns were not applicable to transference interpretations as well as to nontransference interpretations.

The method used is conversation analysis (CA). It is a qualitative approach for the study of the structure and process of social interaction (see Heritage, 1984; Schegloff, 2006). CA concentrates on 'how' (rather than 'what' or 'why') questions, describing how interaction is organized so as to produce co-ordinated actions such as questions and answers, openings and closings of conversation, or turn taking. CA studies focus on intersubjective (rather than intrasubjective) phenomena: the ways in which participants to 
interaction display, and orient to, each others' intentions and understandings through their verbal and non-verbal expression. As data, conversation analytical studies use video or audio recordings of naturally occurring social interactions. The recordings are transcribed using detailed notation developed by Gail Jefferson (see e.g. Schegloff, 2006). In the actual data analysis, however, the researchers frequently go back to the initial (audio or video) recordings rather than working on transcriptions only.

The analytical procedure in CA studies begins from unmotivated exploration of data (often taking place in groups) which leads to identification of recurrent interactional phenomena (such as 'third interpretative turns'). The researcher then collects all instances of the phenomenon from his or her database; thereafter, through case-by-case qualitative analysis and comparisons between cases, he or she specifies the variation of the phenomenon and its interactional conditions and consequences (for a more detailed description, see Peräkylä, 2004a).

CA has been widely used in the study of different types of professionalclient interaction, such as counselling (e.g. Peräkylä, 1995; Silverman, 1997) and medical consultations (e.g. Heritage and Maynard, 2006). More recently, a number of researchers have taken up CA in research on psychotherapy, as reflected by a recent collection of such studies (Peräkylä et al., 2008; see also Buttny, 2001; Elliott, Slatick and Urman, 2001, pp. 94-8; Forrester and Reason, 2006; Lepper and Mergenthaler, 2007; Streeck, 2001). This article originates in the first conversation analytical research project on psychoanalysis. As a strictly empirical research method, CA can complement other approaches, such as the one recently developed by Tuckett et al. (2008) which seeks for data-driven descriptions of what actually happens in psychoanalytic sessions.

The core contribution of $\mathrm{CA}$ in research on professional-client interaction is the meticulous description of practices through which participants accomplish their tasks, in this case those of an analyst and an analysand. Typically, conversation analytical studies focus on the design of the utterances (choice of words, syntactic properties, intonation, rhythm and other prosodic features) which contribute to these tasks, as well as the sequential relations between such utterances (Drew and Heritage, 1992). That will be the case in this paper, too: I will examine the design of the analysts' third interpretative turns that come after the patients' responses to interpretations, and the sequential relations between the analysts' and the patients' utterances.

\section{Earlier conversation analytic research on interpretations}

Interpretation has been one of the key topics in the recent conversation analytical research on psychotherapy. Vehviläinen (2003, 2008) and Peräkylä (2004a) have shown some ways in which psychoanalysts prepare for interpretations, for example, by formulating patients' utterances so as to invoke puzzles which the interpretation later on solves, or by choosing words and descriptions for their formulations that afford linguistic connections to be made between different domains of experience (such as past and present). Equally, patients' responses to interpretations have been explored. Studies 
by Peräkylä $(2005,2008)$ and Bercelli et al. (2008) show striking similarities between psychoanalysis on the one hand, and cognitive and systemic therapies on the other. In all of them, the 'default' response to an interpretation is what Peräkylä calls elaboration (and Bercelli et al. call extended agreement): an utterance by the patient where he or she takes up the interpretation and not only claims agreement (which can be done minimally by saying for example 'yes' or 'you are right') but, rather, continues talking about a topic opened up by the interpretation, thereby showing his or her acceptance and understanding of the interpretation. Both in psychoanalysis and in cognitive and systemic therapies, analysts/therapists work towards facilitating such elaborations, for example, by adding new elements to interpretations that have already been finished and to which the patient has produced only a minimal response, so as to make it possible for the patients to produce a more extended response, i.e. an elaboration.

Even though patients' elaborations manifestly convey agreement with the interpretation, they can also have more subtle functions relative to it. Peräkylä (2005) suggested that the patient's elaborations can be in various ways and degrees selective in relation to the interpretation that precedes them. In other words, the patient's elaborations often take up only a particular aspect of the interpretation, leaving aside other aspects. Arguably, this selectiveness can be a vehicle for implicit resistance towards the interpretation.

In this paper, I will follow up the interpretative trajectory after the patient's elaboration. So I will not deal with cases where the patient, for example, rejects the interpretation or responds only minimally (e.g. by saying 'you are right') in spite of the analyst's efforts to elicit a more elaborate response. Cases that I will focus on - ones where the patients produce elaborations - are instances of successful interpretations: in them, the interpretation indeed seems to work as the patient takes it up and starts to talk in his own terms about it - or, to put it in Casement's (2002) terms, uses the interpretation and makes something of it.

\section{Third interpretative turn}

After the patient has produced an elaboration of an interpretation, there is a chance for the analyst to act. The analyst's action takes place in what in conversation analysis is called (see Schegloff, 2006, pp. 118-68) third position: the analyst is working upon the response (2nd position) that the patient produced upon the analyst interpretation (1st position). Given that the concept of 'third position' has an entirely different meaning in psychoanalytic theory concerning interpretations (see especially Kernberg, 1997), I will avoid the term in this paper and will talk about third interpretative turn instead. The reader, however, needs to be reminded that I am not referring to just any third turns that come after the patient's response, but, instead, to utterances in which the analyst in one way or another deals with the understandings indicated by the patient's response.

In this paper, I will focus on third turns which maintain the interpretative activity. Such utterances are statements that continue the description of the 
patient's mind or circumstances, in the general frame that was established in the interpretation. In our data, they are the most common way for the analysts to respond to the patient's elaborations. (There are some far less frequent third turn actions in our data which halt the interpretative activity such as analyst's questions regarding the factual details referred to in the patient's elaboration. I will not deal with them in this paper. Neither will I deal with the equally rare cases where the analyst in effect rejects the patient's elaboration and repeats his/her initial interpretation.)

I will be describing the ways in which the analysts' third interpretative turns are related to the patients' understandings of the interpretation, as shown in the preceding utterance (elaboration). It will be shown that the third interpretative turns in my data very seldom merely mirror or echo the patients' understandings incorporated in the elaboration. The third interpretative turns do ratify and accept these understandings but, in addition to that, they also introduce a shift of perspective relative to the elaboration. In most cases, the shift of perspective is implicit and subtle. Sometimes, this shift is explicit and manifest. In what follows, examples of each type will be analysed.

\section{Implicit perspective shifts}

In most cases, the analysts' third interpretative turns redirect the patients' attention in a subtle and non-prominent way to aspects of experience that were not attended to in the patients' preceding utterances (i.e. in the patients' elaborations). These aspects of experience are often also implications of the initial interpretations that the patients' elaborations did not take up. Importantly, the implicit shifts of perspective take place under the auspices of the apparent alignment between the patient's and the analyst's utterances.

In this type of third interpretative turn, the analyst continues the description of the patient's mind and/or circumstances, presenting his description as one that is in line with the patient's elaboration. By aligning with the elaboration, the analyst indicates that, here and now, the patient's response to the interpretation was adequate in relation to the therapist's intention. The shift in perspective is done, as it were, implicitly. In sequential terms, the third interpretative turns with implicit perspective shift are often 'closing relevant'. They suggest the possibility (but not necessity) of closing the interpretative sequence and the topic of the interpretation - in a somewhat similar, but less straightforward, way as 'thank you' in everyday talk suggests the closing of the sequence and topic after a question and an answer, such as 'Do you know what's the time?' - 'Quarter to two' - 'Thank you' (cf. Schegloff, 2006, p. 108).

Extract 1 involves an example of an implicit perspective shift. In his long interpretation (only the latter part of which is shown here), the analyst suggests that the patient's disappointment at his mother for not supporting his athletic hobby when he was a teenager, in fact, involves a 'deeper' disappointment at the fact that the mother was not father. (The patient's father had left the family when the patient was on his early teens.) When the 
extract begins, the analyst is about halfway in the interpretation. After the number of the extract, the information given indicates the number of the segment in the collection of interpretations (Tul 6:3) which is followed by the identification of the analyst and the patient. 1A indicates that the segment comes from analyst number 1 and patient $\mathrm{A}$. Where the initial interpretation is, is indicated by box 1, the patient's response (elaboration) by box 2, and the analyst's third interpretative turn by box 3 . For transcription symbols, see Appendix.

\section{Extract 1. (Tul 6:3; 1A)}

\begin{tabular}{|c|c|c|c|}
\hline $\begin{array}{l}01 \\
02\end{array}$ & AN: & $\begin{array}{l}\text { I think that it's actually difficult for you, } \\
(1.2)\end{array}$ & \multirow{17}{*}{1} \\
\hline $\begin{array}{l}03 \\
04\end{array}$ & AN: & $\begin{array}{l}\text { to admit that that (.) you didn't didn't have a father. } \\
\text { (1.2) }\end{array}$ & \\
\hline $\begin{array}{l}05 \\
06\end{array}$ & AN: & $\begin{array}{l}\text { So that it was as it were mother's fault, } \\
\text { (1.3) }\end{array}$ & \\
\hline $\begin{array}{l}07 \\
08\end{array}$ & AN: & $\begin{array}{l}\text { that the father wasn't there. } \\
(0.7)\end{array}$ & \\
\hline 09 & AN: & And it shows in this way that $(0.2)$ you & \\
\hline 11 & \multirow{5}{*}{ AN: } & the father would have had. & \\
\hline 13 & & \multirow{4}{*}{$\begin{array}{l}\text { And (.) you are (dissatisfied) now with the mother for } \\
\text { the fact }(0.7) \text { that the mother didn't have those } \\
\text { characteristics. } \\
(1 . \overline{6})\end{array}$} & \\
\hline 14 & & & \\
\hline 15 & & & \\
\hline 16 & & & \\
\hline $\begin{array}{l}17 \\
18\end{array}$ & AN: & $\begin{array}{l}\text { That mother wasn't father. } \\
\text { (3.5) }\end{array}$ & \\
\hline 19 & AN: & It's the father's (1.0) duty (.) normally & \\
\hline 20 & & (1.0) () to encourage $(0.5)$ the son to o- & \\
\hline $\begin{array}{l}21 \\
22\end{array}$ & & $\begin{array}{l}\text { outdoor activities and sports. } \\
(6.0)\end{array}$ & \\
\hline 23 & AN: & To hunting expeditions and, & \\
\hline 24 & & $(1.5)$ & \\
\hline 25 & AN: & to athletic fields and so on. & \\
\hline $\begin{array}{l}26 \\
27 \\
28\end{array}$ & PA: & $\begin{array}{l}(18.5) \\
((\text { sighing })) \\
(6.2)\end{array}$ & \\
\hline $\begin{array}{l}29 \\
30\end{array}$ & PA: & $\begin{array}{l}\text { Yeah, (.) It is true (.) true of course, It is } \\
\text { father who should have been there by the atheltic field. }\end{array}$ & \\
\hline 31 & & $(\overline{0} .8) \quad--100$ & 2 \\
\hline 32 & PA: & Whooping. Shouldn't he. & \\
\hline $\begin{array}{l}33 \\
34\end{array}$ & AN: & $\begin{array}{l}\text { Yeah. } \\
(10.0)\end{array}$ & \\
\hline $\begin{array}{l}35 \\
36\end{array}$ & AN: & $\begin{array}{l}\text {.hh And in the steering committee of the athletic club } \\
\text { (1.0) supporting the youngsters' work. }\end{array}$ & 3 \\
\hline 37 & & $(5.2)$ & \\
\hline 38 & PA: & Yeah & \\
\hline 39 & & $\overline{(3} 5.0)$ & \\
\hline
\end{tabular}

After a long silence (in lines 26-28) following the completion of the last element of the interpretation, the patient in line 29 produces first a claim of agreement, and thereafter (in lines 29-32) an elaboration where he takes up the perspective that was incorporated in this last element of the 
interpretation (lines 19-22) where the analyst described fathers' conventional duties that the patient's father failed to live up to. In his elaboration (lines 29-32) the patient expands this description with a concrete hypothetical sketch of his father cheering ("whooping") for him. The description is followed by a tag "shouldn't he" (line 32), whereby the patient invites the analyst to confirm what he has just said. After a minimal confirmation in line 33, the analyst remains silent for ten seconds, and then produces a third interpretative turn that involves continuation of the patient's elaboration.

The analyst's utterance is aligned with the patient elaboration. The alignment is achieved through the design of the utterance. It is syntactically fitted to the patient's utterance, expanding the same sentence structure that was there in the patient's utterance (cf. Lerner, 1991; Vehviläinen, 2003). The analyst adds another element to the jointly produced description of what the patient's father should have done but failed to do. Through this third interpretative turn, the analyst shows (though in a delayed fashion) his acceptance of the patient's elaboration and the understanding of the interpretation incorporated in it. The patient then in line 38 (after a gap) receives the analyst's utterance with minimal agreement "yeah". Thereby, the interpretative action is brought to a point where it could be closed, and a long silence ensues.

Under the auspices of alignment and agreement in his third interpretative turn, the analyst in Extract 1 accomplishes a subtle shift of perspective. In the first place, the shift involved movement from the image, in the patient's elaboration, of the father as one who cheers for his son's achievement, to an image of the father as one who steers and supports the youthwork. This shift has at least two facets, both of which are relevant for the psychoanalytic interpretive activity.

Firstly, there is a shift from what one might call a dependent father to an independent father. In the patient's elaboration, the father was cheering for his son. The original Finnish word translated here as "whooping" [hihkumassa] involves a somewhat child-like connotation. The father's action is dependent on the son's achievements on the athletics ground. In the analyst's third interpretative turn, the image of the father foregrounds his independent power as someone who facilitates the new generation's activities. Secondly, there is a shift from a relation where the son earns his father's attention (as the father is whooping for the son's achievement) to a relation where the father supports his son. Through both facets of the shift, the analyst can be heard to intensify the sense of loss that he (in the interpretation) suggested the patient is feeling (without acknowledging it) due to the absence of the father. By intensifying the sense of loss, he also in a way empathizes with the patient who has been subjected to the loss.

The next two examples also involve such implicit shifts. Let us consider Extract 2 below. Prior to this extract, the female patient has spoken about her worry that she might not be able to overcome her grief after the recent death of her partner. 
Extract 2. (Tul 4:1, 1B)

\begin{tabular}{|c|c|c|c|}
\hline $\begin{array}{l}01 \\
02\end{array}$ & $\begin{array}{l}\text { PA: } \\
\text { AN: }\end{array}$ & $\begin{array}{l}\text { or that I will become like [that } \\
{[((\text { coughs })) \mathrm{hmm}}\end{array}$ & \\
\hline 03 & & (.) 1 & \\
\hline 04 & PA: & old relative of mine so I will just walk & \\
\hline 05 & & around then and say oh I wish I could get away. & \\
\hline 06 & & $(1 \overline{0})$ & \\
\hline $\begin{array}{l}07 \\
08\end{array}$ & PA: & $\begin{array}{l}\text { I mean that is no }(0.3) \text { way to live. } \\
(0.4)\end{array}$ & \\
\hline $\begin{array}{l}09 \\
10\end{array}$ & PA: & $\begin{array}{l}\text { You either live or you don't live. } \\
(1.8)^{-}\end{array}$ & \\
\hline $\begin{array}{l}11 \\
12 \\
13 \\
14\end{array}$ & AN: & $\begin{array}{l}. \text { hhh I do think that it has }(0.5) \text { uh considerable } \\
\text { dimensions that thing so that it again I would } \\
\text { indeed connect it to your }(0.4)^{-} \text {child hood situations } \\
\text { to these } \overline{(.)} \text { gre[at sorrows. }\end{array}$ & \\
\hline 15 & PA: & [Yeā̄, & 1 \\
\hline 16 & & $(0.3)$ & \\
\hline $\begin{array}{l}17 \\
18\end{array}$ & AN: & $\begin{array}{l}\text { When you have the kind of feeling that they must just } \\
\text { (0.4) be left behind right away. }\end{array}$ & \\
\hline 19 & & $(0.5)$ & \\
\hline 20 & PA: & ye[:s (just-) & \\
\hline 21 & AN: & [One shouldn't be drawn in[to grieving. & \\
\hline 22 & PA: & $-\quad[$ To dance and to sing. & \\
\hline 23 & & - & 2 \\
\hline 24 & AN: & Yes, & \\
\hline 25 & PA: & So that others would be happy (.) and pleased with me. & \\
\hline 26 & & (.) & \\
\hline 27 & AN: & Yes and you too would feel better. & 3 \\
\hline 28 & & $(2.3)$ & \\
\hline
\end{tabular}

In lines 11-21, the analyst offers an interpretation where he suggests that the patient's worry about getting stuck in her grief is related to her adverse childhood experiences of having just to leave behind great sorrows. In her elaboration the patient first (lines 20,22) animates her childhood attitude in figurative language ("yes, just [...] to dance and to sing"), and thereafter (line 25) moves on to explain that attitude with reference to the expectations of 'others'. In response to the patient's elaboration, the analyst first produces two agreement tokens (lines 24,27 ) and, immediately following the second agreement token, adds another 'explanatory aspect': 'dancing and singing' made the patient herself also feel better. Here, as in Extract 1 above, the analyst's third interpretative turn is syntactically fitted to the patient's previous turn and adds another element to the jointly produced description. This, alongside the turn beginning "yes and" (line 27), presents the analyst's third interpretative turn as one that aligns with the patient's preceding elaboration. However, there also occurs an implicit perspective shift: while the patient refers to "others" expectations as a reason for repressing her grief, the analyst suggests that the patient herself also needed, and benefited from, that repression. The shift of perspective involves movement from a view where the patient (in her elaboration) attributes the origin of her difficulty 
to others, to a view where the dynamics of her own mind have taken part in producing the inability to mourn. ${ }^{1}$

The next example also involves an implicit shift of perspective. In this case, the shift, although implicit, is particularly sharp. Before the segment, and repeatedly throughout this session, the participants have been talking about the patient's tendency to avoid talking 'freely' during the analytic sessions. The analyst has pointed out that the patient, instead of letting his talk flow in free associations, controls what he is saying. The analyst's interpretation (shown in Extract 3, Box 1, below) suggests an explanation to that: the patient wants to analyse things himself in order not to become dependent on, and surprised by, the analyst's interpretations. In his elaboration (Box 2 ), the patient confirms and takes this up.

\section{Extract 3. (Tul K1; C15)}

\begin{tabular}{|c|c|c|c|}
\hline $\begin{array}{l}01 \\
02 \\
03 \\
04 \\
05 \\
06 \\
07\end{array}$ & AN: & 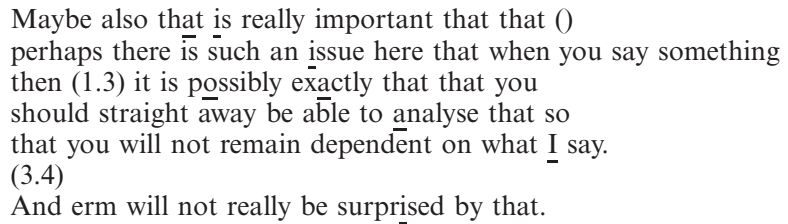 & 1 \\
\hline 08 & & $(4.7)$ & \\
\hline $\begin{array}{l}09 \\
10 \\
11 \\
12 \\
13\end{array}$ & $\begin{array}{l}\text { AN: } \\
\text { PA: }\end{array}$ & $\begin{array}{l}\text { So perhaps as it were I'm doing the kind of first } \\
\text { screening already here. } \\
\text { (.) } \\
\text { Yeah, } \\
\text { Like completing it here, }\end{array}$ & 2 \\
\hline $\begin{array}{l}14 \\
15 \\
16\end{array}$ & AN: & $\begin{array}{l}(0.7) \\
\text { Yeah, } \\
\overline{(2.7)}\end{array}$ & \\
\hline $\begin{array}{l}17 \\
18 \\
19 \\
20 \\
21 \\
22 \\
23 \\
24\end{array}$ & $\begin{array}{l}\text { PA: } \\
\text { AN: } \\
\text { PA: }\end{array}$ & $\begin{array}{l}\text { Yeah } \\
\text { [And ] so the frightening situation is perhaps that } \\
\text { [(that's how)-] } \\
\text { you're talking happily chatting away and all of a } \\
\text { sudden I will give an awful interpreta[tion. } \\
\text { [heh Yes, } \\
\text { Which will catch you as it were pants } \\
\text { dow[n. }\end{array}$ & 3 \\
\hline $\begin{array}{l}25 \\
26\end{array}$ & PA: & $\begin{array}{l}\text { [Pants down yeah. } \\
\text { (11.7) }\end{array}$ & \\
\hline
\end{tabular}

While taking up the interpretation in his elaboration (Box 2), the patient focuses on his tendency to control his talking, describing how he, on his own, examines the contents of his mind, before expressing them to the analyst. While thus taking up one part of the analyst's interpretation (see lines 1-4), the patient at the same time focuses away from the other part (lines 5-7): dependency and being surprised, the avoidance of which the analyst suggested is the underlying motivation for the patient's controlled talking.

\footnotetext{
${ }^{1}$ See Peräkylä (2008) for the continuation of Extract 2. In subsequent interaction not shown here, the analyst produces what in this paper is called an explicit shift of perspective, making this extract in fact a hybrid case in which implicit and explicit shifts go together.
} 
The analyst first receives the elaboration with two response tokens which have an element of agreement in them (lines 12,15). In his third interpretative turn (Box 3), the analyst then adds a new element to the jointly constructed description. Through the turn beginning "and so", the analyst's utterance presents itself as being in line with what the patient has suggested. It also treats the patient's utterance as a valid response to the interpretation, as an adequate ground for continuing the exploration of the patient's mind.

However, an implicit shift of perspective also takes place in this third interpretative turn. Instead of focusing on the ways in which the patient's mind controls his flow of talk (the focus of the patient's elaboration), the analyst's third interpretative turn re-invokes the motivational and relational perspective that was there in the analyst's interpretation. The analyst builds up a hypothetical, humiliating scene between himself and the patient and suggests that the patient wants to avoid this scene by controlling his talk. The scene is depicted using strong emotional words: "frightening situation"; "happily chatting"; "all of a sudden"; "awful interpretation"; "catches you"; "pants down". While the patient's elaboration described, in affectively neutral terms, his self-control, the analyst's third interpretative turn focuses on the strong affects that may lie behind this self-control. Similarly, while the patient's elaboration described the solitary workings of his mind, the analyst's third interpretative turn took up the transference. So, under the auspices of continuity, the analyst in turn proposes a shift of perspective to the matters that are being interpreted.

In this section, I have examined analysts' third interpretative turns that involve implicit shifts of perspective in relation to patients' elaborations that precede them. These shifts put to the foreground and thus bring to joint attention some aspects or implications of the initial interpretation that the patient's elaboration did not take up. In so doing, the third interpretative turns recast the way in which the patient's current or past experience is attended to in the interaction. There are two basic facets in this recasting: one is to show that the experience is emotionally more intensive than what the patient indicated in the elaboration, and the other one is to show that it has more layers in it. Sometimes one and sometimes the other is the more prominent facet.

Thus, in Extract 1, the third interpretative turn can be heard to intensify the patient's unacknowledged sense of loss of father, and to show a new dimension of strength and independence in the missed object. In Extract 2, the third interpretative turn shows a new layer of experience by emphasizing the dynamics of the patient's own mind (rather than expectations of others) in producing her inability to mourn, and in so doing, it also depicts the patient's current and past suffering in more intensive terms than the patient's elaboration did. Likewise, in Extract 3, the analyst's third interpretative turn brings in the layer of transference to the depiction of the patient's experience of not being able to associate, and, at the same time, this third interpretative turn intensifies the emotional undertone in the depiction of this experience.

In bringing to the foreground aspects or implications of the initial interpretation that the patient's elaboration did not take up, the third interpretative turns in some cases return to something that was first suggested in the initial interpretation and that the patient's elaboration failed to take up, and 
in other cases, the third interpretative turn brings in something new that is contingent upon the patient's elaboration, but was not there in the initial interpretation. The aspect of return is strong in Extract 3, where the initial interpretation referred to transferential feelings and expectations, the elaboration did not take them up, and the third interpretative turn brought them back. On the other hand, in Extract 2, the perspective shift in the third turn to the dynamics of the patient's own mind (in producing her inability to mourn) appears to be contingent upon, and responsive to, the patient's invoking 'others' expectations' in her elaboration as a reason for her reluctance to mourn, and does not as such pursue a theme that would also have been there in the initial interpretation.

Importantly, the implicit shifts of perspective occur in third interpretative turns that are designed as ones that align with the patient's elaborations. The alignment means that the analyst continues the description from the point where the patient ended, which is achieved by joint construction of syntactic units and by the use of turn initial particles 'yes' and 'and'. By designing his or her third interpretative turns as aligned with the elaboration, the analyst in the first place indicates that (s)he considers the patient's elaboration as an 'adequate' response to the initial interpretation. It is therefore that the shifts of perspective in these utterances are implicit rather than explicit. They are not open and not manifest. They take place under the auspices of the alignment between the patient's and the analyst's utterances. Moreover, as the analyst's aligned third interpretative turns are usually close implicative, the patient is not invited to show his or her collaboration with the shift of perspective. The new aspects of experience, introduced through the implicit shifts of perspective, are in these cases 'left in the air' so to say, possibly for the patient to remember and make use at some later point. ${ }^{2}$

\section{Explicit perspective shifts}

The implicit perspective shifts analysed in the preceding section occur in the analyst's third interpretative turns that are aligned with the patient's elaboration. In these cases, the design of the third interpretative turn does not 'point out' that a shift of perspective is taking place. In some cases, however, the analyst openly shows that (s)he is proposing a new perspective which is discrepant with some aspect of the patient's talk. In such cases, the analyst third interpretative turn is designed to be misaligned - not quite in line with the patient's preceding elaboration. The analyst's utterance openly suggests that the patient's elaboration was in some way insufficient in capturing what the participants are describing, and the analyst, through his or her third interpretative turn, suggests a new perspective to be attended to. This suggestion for a new perspective is made in an open and explicit way. The third interpretative turns that introduce such an explicit shift of perspective are regularly designed as ones that seek the patient's response: unlike utterances with implicit shifts of perspective, these are not close implicative, but suggest the continuation of talk in the new direction.

\footnotetext{
${ }^{2}$ See Peräkylä (submitted) for ways in which the shifts are reinvoked in subsequent sessions.
} 
But even in these cases, the analyst's third interpretative turns treat the patient's elaboration as a relevant response to the interpretation and a possible basis for the continuation of the interpretative activity. These third interpretative turns are designed as ones that are tied to the elaboration, as ones that take up the elaboration and affirm it - and then, in an explicit way, redirect the talk.

Extract 4 below is a case in point. In the interpretation (see Box 1), the analyst makes a link between the male-female conflicts at the patient's workplace (worry over which the patient has been describing in the prior interaction) and the conflict between mother and father in the patient's childhood family. In the last element of the interpretation (lines 16-20), the analyst suggests that the patient is (now) anxious because he might have to take sides between conflicting parties at the workplace, as he had to take sides as child in the context of his parent's marital conflict. To understand this interaction, the reader also needs to know that, in an earlier part of the session, the patient has reported a dream where a cow grabbed him in the neck, and in the subsequent discussion the participants have agreed that the cow in the dream represents women in the patient's life.

\section{Extract 4. (Tul 2:8, 1A)}

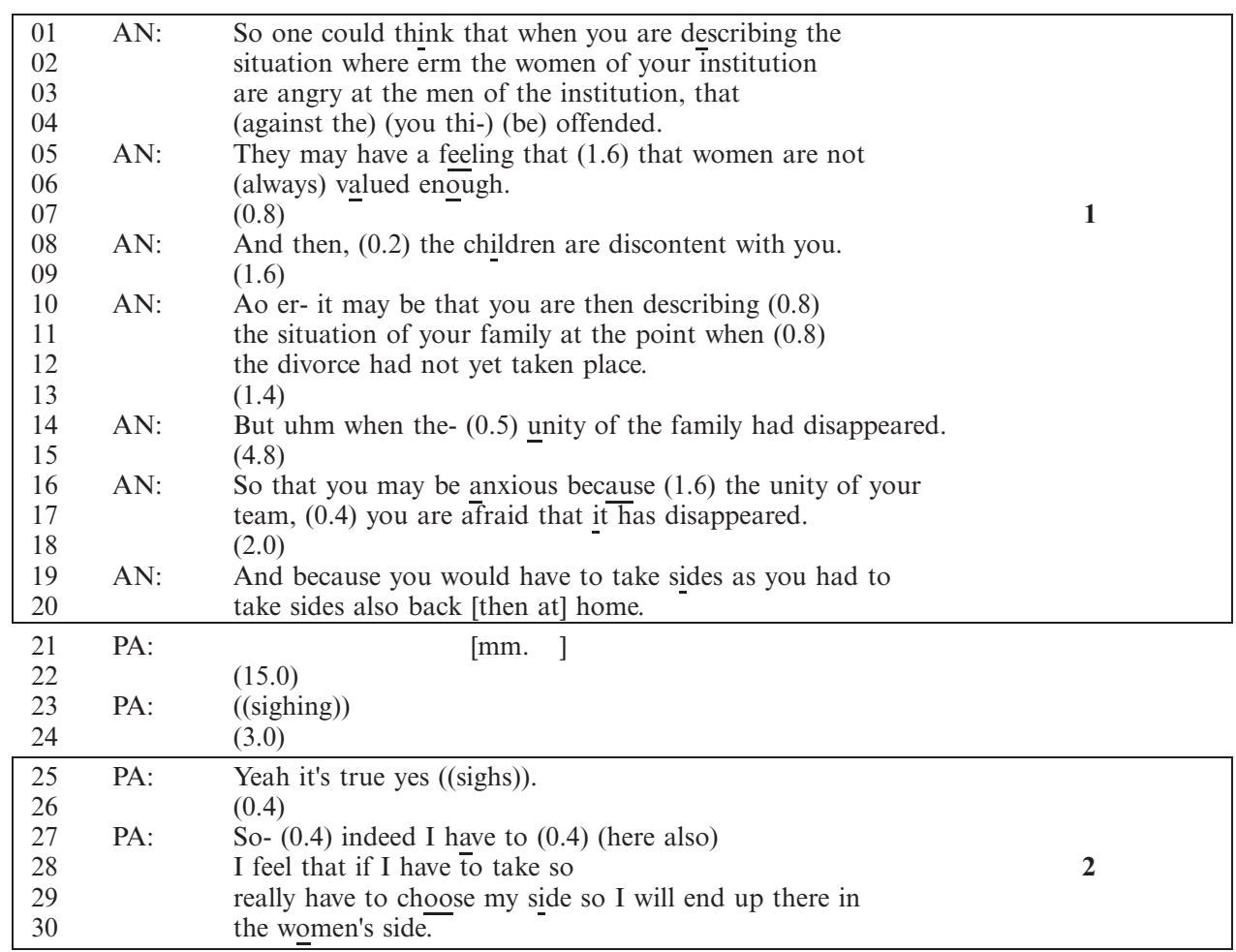


Extract 4. (Tul 2:8, 1A) (Continued)

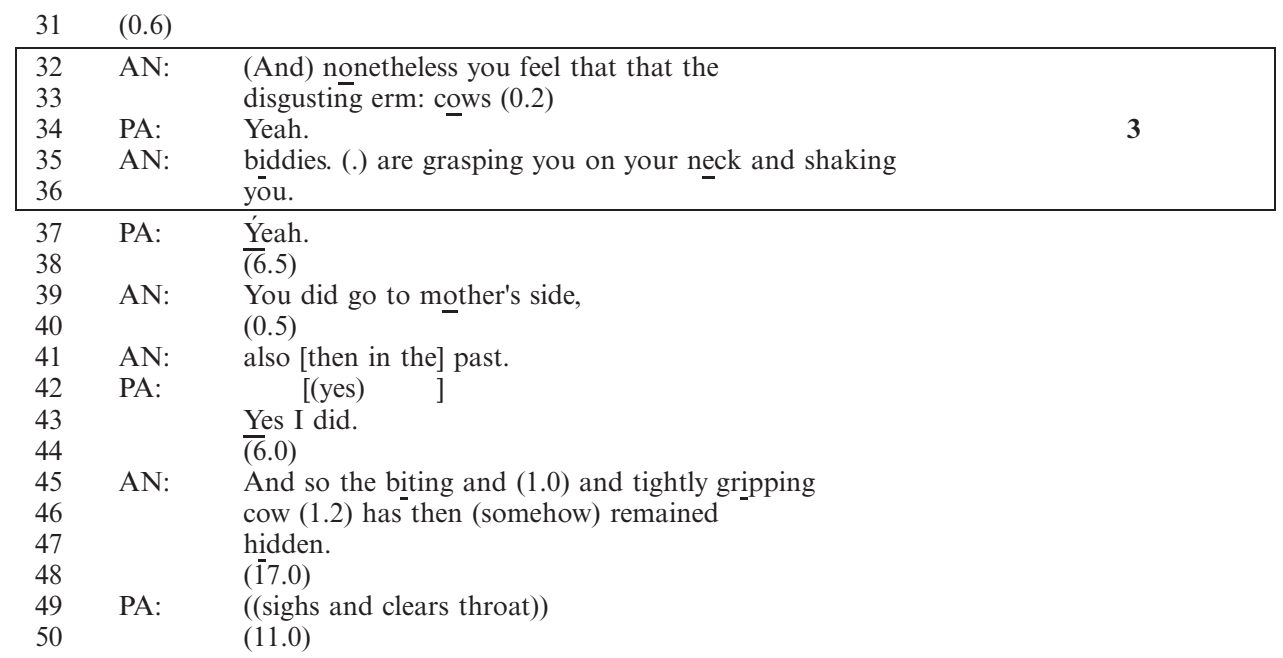

In his elaboration (Box 2), the patient takes up the last element of the analyst's interpretation. He points out that, if he has to take sides, he will go to the women's side. In his third interpretative turn, the analyst then (Box 3) suggests - through an allusion to the patient's dream discussed earlier in the session - that in spite of him going to the women's side, the patient's relation to women is conflict ridden: he feels that the women ("disgusting cows") control him and treat him badly (grab and shake him). Turn initial "nonetheless" (possibly preceded by 'and') frames the analyst's third interpretative turn as one that is misaligned with the patient's earlier turn. The analyst openly proposes a shift of perspective: from one that focuses on the alliance between the patient and the "women" to one that focuses on conflict between them. The conflict is depicted in strong emotion relevant words, such as "disgusting", "cows", "biddies" and "shaking you".

The patient responds minimally to the analyst's third interpretative turn (see line 37). After a silence (line 38), the analyst then re-issues and further develops his point in two parts (lines 39-41, 45-7). Now the analyst suggests that the feeling of being controlled by women was there already in the patient's childhood relation with his mother. By pursuing his point, the analyst also indicates an expectation that the patient would take up the new perspective, but the patient remains passive (see lines 40-50).

The analyst offers his third interpretative turn as one that is misaligned with the patient's elaboration of the interpretation. At the same time, however, the third interpretative turn is tied to the elaboration, as it takes up the central theme of the elaboration, the patient's tendency to associate with women. The analyst enters into the same descriptive scene, as it were, where the patient is in his elaboration. He treats the patient's elaboration as a relevant response to the interpretation and a possible basis for the continuation of the interpretative activity. The affirmation of the elaboration is also manifested in analyst's way of pursuing his point (in lines 39 and 41) after the 
patient's initial response: by pointing out that the patient "did go to the mother's side also then in the past", the analyst echoes the patient's proposal in lines 29-30 ("I will end up there in the women's side"), thus showing that what the patient said was valid as such.

Extract 5 is yet another case where the analyst's third interpretative turn involves an explicit shift of perspective. During the time of the session, the patient's partner was seriously ill and the patient was talking about her feelings and experiences while taking care of him.

\section{Extract 5. (Tul 1:24, 1B)}

\begin{tabular}{|c|c|c|c|}
\hline $\begin{array}{l}01 \\
02 \\
03 \\
04 \\
05 \\
06 \\
07 \\
08 \\
09\end{array}$ & $\begin{array}{l}\text { AN: } \\
\text { PA: }\end{array}$ & $\begin{array}{l}\text { As I had a dream that I had been }(0.6) \text { quite } \\
\text { insane for a few days. } \\
(0.8) \\
\text { Yea[h. } \\
\quad \text { [so as one }(0.4) \text { as as one probably wants to } \\
\text { (1.8) empathize the (1.6) patient in his (1.1) } \\
\text { condition and his situation and and one wants to go } \\
\text { along with it, }(0.4) \text { then }(2.9) \text { one goes too far. } \\
(6.2)\end{array}$ & \\
\hline $\begin{array}{l}10 \\
11\end{array}$ & AN: & $\begin{array}{l}\text { Probably in the same time you also repress the } . \text { hh the } \\
\text { immense grief that [(arises) from that] }\end{array}$ & 1 \\
\hline $\begin{array}{l}12 \\
13 \\
14 \\
15 \\
16 \\
17 \\
18\end{array}$ & PA: & $\begin{array}{l}\text { [Yeah. then it is is] is ((clears throat)) } \\
\text { hh impossible .hhhh ((coughs)) to erm deal }(0.2) \\
\text { really with }(0.6) \text { that grief because }(.) \text { one has to act } \\
\text { all the time. } \\
(0.4) \\
\text { Or to be rational and to do dusting and to } \\
\text { order }(0.5) \text { things from pharmacy and }(0.8) \text { and this and that. }\end{array}$ & 2 \\
\hline 19 & & 2.2) & \\
\hline $\begin{array}{l}20 \\
21 \\
22 \\
23\end{array}$ & AN: & $\begin{array}{l}\text { And on the other hand }(0.6) \text { you can also avoid the grief } \\
\text { through this very action. } \\
\text { (1.5) } \\
\text { So that it works b- [both ways }\end{array}$ & 3 \\
\hline $\begin{array}{l}24 \\
25 \\
26 \\
27 \\
28\end{array}$ & $\begin{array}{l}\text { AN: } \\
\text { PA: } \\
\text { AN: }\end{array}$ & $\begin{array}{l}\text { [Yes, but as there is the] } \\
\text { responsibility so it erm some [kind of act] ion has to be } \\
\text { [yes } \\
\text { acc[omplished.] } \\
\text { [It ] has to be done necessarily. }\end{array}$ & \\
\hline
\end{tabular}

Prior to the interpretation, the patient mentions a dream in which she was insane, and then connects the insaneness in the dream to her taking care of her dying partner, suggesting that empathizing with the partner too much may be a kind of insaneness. In his subsequent interpretation (Box 1), the analyst suggests that the patient possibly also represses her own immense grief through intensively empathizing with the seriously ill partner. The patient first agrees with the interpretation through "yeah" token (Finnish nii; line 12) and then hastily moves into elaboration (Box 2). She shows her agreement with, and understanding of, the interpretation by taking up from the interpretation the theme of 'not grieving', and suggesting that, in taking care of the partner, it is impossible for her to deal with grief, as she has to "act all the time". The analyst remains passive at the first possible 
completion of the elaboration (see line 16), and the patient then expands the elaboration in lines $17-18$ by listing the practicalities that she needs to take care of. While the patient elaborates the interpretation, and thereby shows her agreement and understanding, her elaboration is also a particular reading of the interpretation. The analyst's interpretation, phrased as the patient repressing grief, is recast in the patient's elaboration as patient impossibility of grieving. The analyst's third interpretative turn is alive to this difference.

In his third interpretative turn (Box 3), the analyst openly proposes a new perspective by pointing out that focusing on practicalities can also be a means for avoiding the grief. So, while 'not grieving' appeared in the patient's elaboration as something imposed upon the patient by the imperatives of the situation, in the analyst's third interpretative turn, avoidance of grief appears as the patient's own accomplishment, and the practicalities appear as instrumental in realizing this choice. By emphasizing the patient's agency or choice in 'not grieving', the analyst also returns to an aspect of his initial interpretation where he suggested that the patient represses her grief.

The contrast between the patient's utterance (elaboration in lines 12-18) and the analyst's third interpretative turn (beginning in line 20) is here (as it was also in Extract 4) incorporated in the turn beginning. The analyst displays the contrast by the phrase "on the other hand ..." (line 20). This contrast marker is preceded by the connector "and" which shows continuity between the patient's preceding talk (elaboration) and the analyst's third interpretative turn. Taken together, the turn initial "And on the other hand" combines acceptance and shift of perspective. The combination of the acceptance of the patient's elaboration and the explicit perspective shift is also embodied in the way in which the analyst, after the initial non-response by patient (line 22), pursues his suggestion in line 23. By pointing out that "so that it works both ways", the analyst suggests that both are true: that the patient is unable to grieve due to her responsibilities (perspective in the patient's elaboration) and that the patient uses her responsibilities to avoid grieving (perspective in the analyst's third interpretative turn).

To sum up, in Extracts 4 and 5, the analysts' third interpretative turns involved an explicit shift of perspective relative to the patient's elaboration. As the implicit shifts of perspective analysed in the earlier section of this paper, the explicit shifts can involve either that the analyst returns to some themes that he suggested in the interpretation (but were missed in the patient's elaboration) - as was the case in Extract 5 - or that the analyst suggests something new relative to the interpretation and the elaboration as was the case in Extract 4. Like the implicit shifts, the explicit shifts also recast the way in which the patient's current or past experience is attended to in the interaction, by showing that the experience is emotionally more intensive than what the patient indicated in the elaboration, and/or by showing that it has more layers in it. Thus, in Extract 4, the third interpretative turn showed a new layer of experience by suggesting that alongside his willingness to associate with women, the patient also feels that they control him and treat him badly; this new layer of experience also brought about the intensification of the emotional undertone of the description. In Extract 5 , the new perspective involved a new layer of experience (rather than 
intensification of emotion involved in it), as the analyst suggested a relation between 'acting' and 'not grieving' that was also in a different direction from that suggested by the patient in her elaboration.

The analysts' third interpretative turns with explicit perspective shifts have an intriguing duality in them: through them, the analyst accepts the elaboration, while through the same utterance also suggests that the patient's elaboration was in some way insufficient in capturing what the participants are describing and needs redirecting. This duality may be a key to understanding the affordances, for psychoanalytic work, of the explicit shifts. Utterances with explicit perspective shifts can demonstrate, through their very design and sequential location, a psychic conflict to the patient. In psychoanalytic theory, psychic conflict refers to "an opposition between apparently or actually incompatible forces" (Rycroft, 1995, p. 25) within the mind (see also Moore and Fine, 1990, pp. 44-5). The third interpretative turns that involve explicit perspective shifts seem to be particularly apt for demonstrating oppositional forces in the patient's mind. Through his or her elaboration, the patient avows a particular psychic reality - in Extract 4, his tendency to associate with women and in Extract 5, her externally imposed inability to grieve. In their third interpretative turns, the analysts both accept that reality and present an opposed one. In Extract 4, the opposed reality involves the patient's perception of the women as controlling and aggressive towards him, and, in Extract 5, the patient's willingness to use external circumstances to avoid grief. Showing the patient's psychic conflicts to him or her is an essential aspect of the psychoanalytic work. It is quite possible that conflicts can be shown and are shown in single interpretative statements. However, it appears to me that the sequential pattern 'interpretation - elaboration - third interpretative turn' is particularly well suited for demonstrating such conflicts, because in it the two opposing forces can, as it were, reside in different utterances: one in elaboration and the other one in the third interpretative turn. In such a structure, the conflict-ridden inner reality of the patient becomes manifest in the external, intersubjective, co-created reality of interaction.

\section{Discussion}

In this paper, I have suggested that psychoanalytic interpretation is best understood as a succession of three utterances: the analyst's interpretation, the patient's response, and the analyst's third interpretative turn that follows the patient's response. The psychoanalytic work done in the analyst's third interpretative turn has not been fully acknowledged in earlier literature on interpretations. It has been the task of this paper to explicate some key aspects of that work.

Through conversation analysis of tape recordings of 58 psychoanalytic sessions with three patients, I examined cases where the interpretation seems to be successful and 'takes off'. In these interpretative sequences that I have focused on the patients did more than merely agree with the interpretation, by producing elaborations where they took up what was suggested by the analyst, and analysts in their third interpretative turns maintained the 
interpretative activity through statements regarding the patient's mind or circumstances.

My main argument is that there regularly takes place a shift of perspective in the third interpretative turn. Therefore the third interpretative turn is an important locus for the psychoanalytic work. The shift of perspective is most often implicit, but is sometimes made explicit by the analyst. I pointed out two main directions in the shift: one is towards showing that the patient's experience is emotionally more intensive than what the patient indicated in the elaboration, and the other towards showing that the patient's experience has more layers in it. The shifts of perspective in the third interpretative turn can be linked to the selectivity of the patients' elaborations. In their elaborations, patients often address some aspect of the interpretation and leave aside some other aspects of it. The shift of perspective in the third interpretative turn can involve a return to those aspects that were in the initial interpretation but were not taken up by the patient. However, in other cases, the new perspective in the third interpretative turn is something 'new' relative to the initial interpretation and the elaboration, something that is touched off by the elaboration.

The structural correspondence between my findings and Faimberg's (1996, 2005) ideas involves the 'three step' organization of the interpretative cycle. In my data, as in Faimberg's, analysts first put their understandings into words in interpretations. This is followed by the patient's elaboration, in which the patient shows his or her understanding of interpretation. I found that, in their third interpretative turns, the analysts were attentive to the patient's elaborations, and at the same time ratified and redirected the patient's understandings shown in them. Like Faimberg, Schlesinger (1995) also pointed out the importance of the analyst's attentiveness to the patient's response to the interpretation. For him, it was the task of followup interpretation to maintain the disturbance to neurotic systems in the patient, initially brought about by the interpretation, and possibly resisted by the patient through her immediate response to interpretation. My findings regarding third interpretative turns can be read as a specification of patterns of manifest interaction through which processes like listening to listening and follow-up interpretation take place.

It needs to be pointed out that the similarity between my findings and those of Faimberg and Schlesinger is only partial. As a conversation analyst, I have focused on the manifest interaction between analysts and patients, and hence processes to do with the patient's unconscious identifications, or neurosis as a system, are not accessed in my analysis. However, if processes to do with these identifications and/or systems take place in the space following the interpretation, the interactions that I have shown are likely to be their vehicles.

We are now in a position where we can discuss further the relations between the patients' understandings shown in their responses to interpretations (i.e. in their elaborations), and the analysts' ways of reshaping these understandings in their third interpretative turns. In an earlier study (Peräkylä, 2005), I suggested that the selectiveness of the patient's elaborations can be a vehicle for implicit resistance towards the interpretation. Now, on the basis of the current study, we are in a position to deepen the 
discussion on the selectiveness of the elaborations, by considering the ways in which patients' selectiveness is met in the analysts' third interpretative turns.

The qualitative analysis presented in this paper has indicated a number of 'parameters' in the analysts' third interpretative turns: the strength of the perspective shift (i.e. whether it is implicit of explicit), the degree to which the shift involves return to initial interpretation or opens up something new touched off by the elaboration, and the degree to which the shift involves intensification of emotion or points out new layers of experience. While the patients' elaborations are in varying ways selective vis-à-vis the analysts' initial interpretations, they are met by the analysts' third interpretative turns that exhibit the above-mentioned parameters.

The results presented in this paper come from a relatively small dataset. With a larger set of data, and using quantitative approach, it would be possible to explore further the ways in which the analysts and the patients assemble interpretative sequences. We might hypothesize that each analyst-patient dyad creates its specific ways of combining the selectiveness of elaborations with particular choices in terms of the parameters of the third interpretative turns. These choices produce what might be called the interpretative profile of each analyst-patient dyad. Thus, in future studies, we might compare analytic couples, for example, in terms of the degree to which the patients' elaborations are selective, the degree to which the analysts pursue their initial interpretations, or shift into something new, in their third interpretative turns, and in terms of the degree to which the analysts intensify the emotional valence in the third interpretative turns.

Such research should find out whether such profiles are indeed different across psychoanalytic dyads. Furthermore, the change of interpretative profiles through the course of psychoanalytic treatment should be explored (do dyads, for example, move from selective elaborations to less selective elaborations, or from much pursuit of the initial interpretation to shifts into something new in the third interpretative turns), as well as the possible connection between interpretative profiles and the outcome of the treatment.

\section{Appendix}

\section{Transcription symbols}

In the data extracts, a simplified version of the standard conversation analytical notation is used.

$$
\begin{aligned}
& \text { Word Underlining indicates stress or emphasis on a sound or a syllable. } \\
& \text { Left had square brackets on successive lines with different speakers indicate the onset } \\
& \text { of overlapping speech. }
\end{aligned}
$$




\section{Transcription symbols (Continued)}

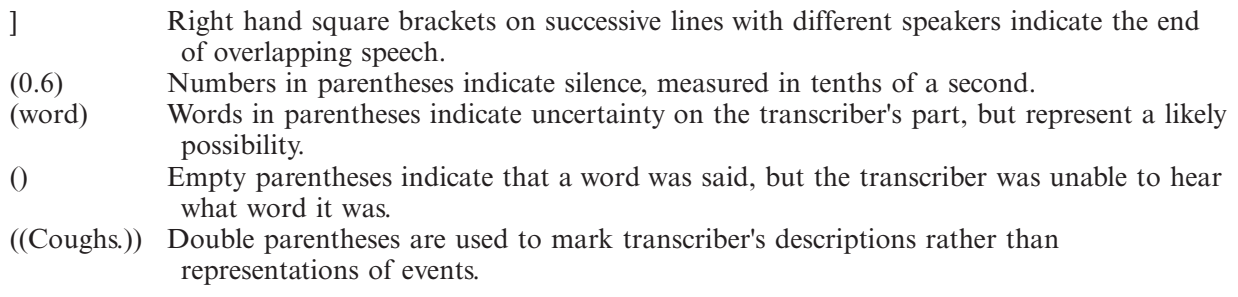

((Coughs.)) Double parentheses are used to mark transcriber's descriptions rather than representations of events.

\section{Acknowledgements}

I gratefully acknowledge the research grants by the Academy of Finland and the IPA Research Advisory Board. I wish to thank the members of the conversation analysis research group at the Department of Social Research, University of Helsinki, as well as Mikael Leiman and Henrik Enckell, for many helpful comments.

\section{Translations of summary}

Perspektivenwechsel im Anschluss an die Reaktion des Patienten auf eine Deutung. Unter der psychoanalytischen Deutung versteht man gewöhnlich die Abfolge von zwei Äußerungen: der Analytiker gibt eine Deutung, und der Patient antwortet darauf. In diesem Beitrag wird die These vertreten, dass die Deutungssequenz noch eine dritte Äußerung enthält, durch die psychoanalytische Arbeit stattfindet. Diese dritte deutende Wende wird durch das Verhalten des Analytikers im Anschluss an die Reaktion des Patienten auf die Deutung konstituiert. Gestützt auf die Konversationsanalyse als Methode, um die Tonbandaufzeichnungen von psychoanalytischen Sitzungen zu untersuchen, erläutert der Beitrag die psychoanalytische Arbeit, die in dieser dritten deutenden Wende erfolgt. Mit ihr bezieht der Analytiker Stellung gegenüber der Art und Weise, wie der Patient, nach seiner Reaktion auf die Deutung zu urteilen, dieselbe verstanden hat. Zum einen wird dieses Verständnis durch die dritte deutende Wende bestätigt und anerkannt; darüber hinaus aber leitet diese auch einen Wechsel der Perspektive auf die weitere Ausarbeitung ein. In den meisten Fällen erfolgt der Perspektivenwechsel implizit, manchmal jedoch wird er artikuliert. Die Perspektivenwechsel rücken Aspekte oder Implikationen der Deutung in den Vordergrund, auf die der Patient in seiner Reaktion nicht eingegangen ist. Sie formulieren die Beschreibung von dessen Erleben um, indem sie neue Schichten oder eine stärkere emotionale Intensität aufdecken. Die Ergebnisse werden im Licht von Faimbergs Konzept des „Hörens auf das Zuhören” und Schlesingers Konzept der „Followup-Deutung" diskutiert.

Cambiar la perspectiva después de la respuesta del paciente a una interpretación. La interpretación psicoanalítica se entiende habitualmente como una secuencia de dos enunciaciones: el analista brinda una interpretación, y el paciente responde a ésta. Este trabajo sugiere que en la secuencia interpretativa existe una tercera enunciación en la que tiene lugar el trabajo psicoanalítico. Este tercer giro interpretativo incluye la acción del analista después de la respuesta del paciente a la interpretación. Usando el análisis conversacional como método para el examen de sesiones de psicoanálisis grabadas, el ensayo explica el trabajo psicoanalítico que tiene lugar durante el tercer giro interpretativo. A través de éste, el analista toma posición respecto de la comprensión de la interpretación por parte del paciente, comprensión que se hace evidente en la respuesta del paciente a la interpretación. El tercer giro interpretativo ratifica y acepta lo que el paciente entiende pero, además, introduce un cambio de perspectiva en relación con la elaboración. En la mayoría de los casos, este cambio de perspectiva es implícito pero, a veces, se hace explícito. Los cambios de perspectiva ponen en evidencia aspectos o implicancias de la interpretación que no habían sido incorporados a la respuesta del paciente. Expresan de otra manera la descripción de la experiencia del paciente, ya que muestran nuevos estratos o una mayor intensidad emocional. Los resultados se analizan a la luz del concepto de Faimberg de escuchar la escucha y del de Schlesinger de interpretación de seguimiento. 
Changements de perspective après la réponse du patient à une interprétation. L'interprétation psychanalytique est généralement considérée comme étant une séquence conjuguant deux énoncés: l'analyste communique une interprétation et le patient y répond. L'auteur de cet article suggère l'idée que cette séquence interprétative comprend également un troisième énoncé où le travail psychanalytique est aussi mis en œuvre. Ce troisième tour interprétatif a trait à l'action de l'analyste après que le patient a répondu à l'interprétation. En se basant sur ce type d'échanges à partir de séances d'analyse enregistrées, l'auteur de cet article tentera d'expliquer le travail analytique effectué lors de ce troisième tour interprétatif où l'analyste se positionne par rapport à la compréhension de l'interprétation par le patient, ce qui est rendu explicite par la réponse du patient à l'interprétation. Ce troisième tour interprétatif constitue d'une part la ratification et l'acceptation de la compréhension du patient, et de l'autre, l'introduction d'un changement de perspective relatif à l'élaboration. Dans la plupart des cas, le changement de perspective est implicite, mais il peut aussi parfois être rendu explicite. Ces changements de perspective mettent en avant certains aspects ou implications de l'interprétation qui n'étaient pas incorporées dans la réponse du patient. Ils remodèlent la description de l'expérience du patient en mettant au jour d'autres niveaux ou une intensité émotionnelle plus forte.

Cambiamento di prospettiva dopo la reazione di un paziente a un'interpretazione. Per interpretazione analitica si intende normalmente una sequenza di due enunciati: l'analista offre un'interpretazione, a cui il paziente risponde. Questo saggio mostra che, all'interno della sequenza interpretativa, esiste anche un terzo enunciato in cui ha luogo l'attività psicanalitica. Questa terza interpretazione comporta l'azione dell'analista dopo la reazione del paziente all'interpretazione. Usando l'analisi conversazionale come metodo di studio di registrazioni audio di sessioni psicanalitiche, questo saggio spiegherà il lavoro psicanalitico esplicato nella terza fase interpretativa. Per mezzo di essa, l'analista prende posizione nei confronti delle valutazioni del paziente sull'interpretazione, evidenziate dalla reazione del medesimo all'interpretazione stessa. La terza fase interpretativa ratifica e accetta, da una parte, i giudizi del paziente, ma oltre a ciò introduce anche un cambiamento di prospettiva rispetto all'elaborazione. Nella maggior parte dei casi, il cambio di prospettiva è implicito, ma talvolta viene reso evidente. I cambiamenti di prospettiva mettono in primo piano aspetti o implicazioni dell'interpretazione non incorporati nella risposta del paziente. Essi ricompongono la descrizione dell'esperienza del paziente mostrando nuovi aspetti o una maggiore intensità emotiva. I risultati vengono discussi alla luce dei concetti 'listening to listening' di Faimberg e di 'follow-up interpretation' di Schlesinger.

\section{References}

Bercelli F, Rossano F, Viaro M (2008). Clients' responses to therapists' reinterpretations. In: Peräkylä A, Antaki C, Vehviläinen S, Leudar I, editors. Conversation analysis and psychotherapy, 43-61. Cambridge: Cambridge UP.

Buttny R (2001). Therapeutic humor in retelling the clients' tellings. Text 21:303-26.

Casement P (2002). Learning from our mistakes. Hove: Brunner Routledge.

Drew P, Heritage J (1992). Analyzing talk at work: An introduction. In: Drew P, Heritage J, editors. Talk at work, 3-65. Cambridge: Cambridge UP.

Elliott R, Slatick M, Urman M (2001). Qualitative change process research on psychotherapy: Alternative strategies. In: Frommer J, Rennie DL, editors. Qualitative psychotherapy research: Methods and methodology, 69-111. Lengerich: Pabst Science Publishers.

Etchegoyen RH (1999). Further thoughts on the testing of the clinical process. J Melanie Klein and Object Relations 17:199-222.

Faimberg $\mathrm{H}$ (1996). Listening to listening. Int J Psychoanal 77:667-77.

Faimberg $\mathrm{H}$ (2005). The telescoping of generations: Listening to the narcissistic links between generations. New York, NY: Brunner Routledge.

Forrester MA, Reason D (2006). Conversation analysis and psychoanalytic psychotherapy: Questions, issues, problems and challenges. Psychoanal Psychother 20:40-64.

Greenson R (1967). The technique and practice of psychoanalysis. New York: International Universities Press.

Heritage J (1984). Garfinkel and ethnomethodology. Cambridge: Polity.

Heritage J, Maynard DW, editors (2006). Communication in medical care. Cambridge: Cambridge UP.

Kernberg OF (1997). The nature of interpretation: Intersubjectivity and the third position. Ann Psychoanal 25:97-110.

Lepper G, Mergenthaler E (2007). Therapeutic collaboration: How does it work? Psychother Res 17:576-87.

Lerner GH (1991). On the syntax of sentences in progress. Lang Soc 20:441-58.

McCullogh L, Winston A, et al. (1991). The relationship of patient-therapist interaction to outcome in brief psychotherapy. Psychotherapy 28:525-33. 
Moore BE, Fine BD (1990). Psychoanalytic terms and concepts. New Haven: Yale UP.

Peräkylä A (1995). AIDS counselling. Institutional interaction and clinical practice. Cambridge: Cambridge UP.

Peräkylä A (2004a). Making links in psychoanalytic interpretations: A conversation analytic view. Psychother Res 14:289-307.

Peräkylä A (2004b). Conversation analysis. In: Seale C, Silverman D, Gubrium J, Gobo G, editors. Qualitative research practice, 165-79. London: Sage.

Peräkylä A (2005). Patients' responses to interpretations: A dialogue between conversation analysis and psychoanalytic theory. Communication and Medicine 2:163-76.

Peräkylä A (2008). Conversation analysis and psychoanalysis: Interpretation, affect and intersubjectivity. In: Peräkylä A, Antaki C, Vehviläinen S, Leudar I, editors. Conversation analysis and psychotherapy, 100-19. Cambridge: Cambridge UP

Peräkylä A (submitted). After interpretation. Third position utterances in psychoanalysis. Manuscript in editorial review.

Peräkylä A, Antaki C, Vehviläinen S, Leudar I, editors (2008). Conversation analysis and psychotherapy. Cambridge: Cambridge UP.

Rycroft C (1995). A critical dictionary of psychoanalysis. 2nd edn. London: Penguin.

Schegloff EA (2006). Sequence organization: A primer in conversation analysis. Cambridge: Cambridge UP.

Schlesinger $\mathrm{J}$ (1995). The process of interpretation and the moment of change. J Am Psychoanal Assoc 43:663-88.

Schuller R, Crits-Christoph P, Connolly MB (1991). The resistance scale: Background and psychometric properties. Psychoanal Psychol 8:195-211.

Silverman D (1997). Discourses of counselling: HIV counselling as social interaction. London: Sage.

Spence DP (1982). Narrative truth and historical truth: Meaning and interpretation in psychoanalysis. New York, NY: Norton.

Spence DP (1995). When do interpretations make a difference? A partial answer to Fliess's Achensee question. J Am Psychoanal Assoc 43:689-712.

Spence DP, Dahl H, Jones EE (1993). Impact of interpretation on associative freedom. J Consult Clin Psych 61:395-402.

Streeck U (2001). 'Ja, genau, genau.' Bestätigungen als Versuche des Patienten, die Kompetenz des Psychotherapeuten als eigene zu deklarieren. Eine gesprächsanalytische Untersuchung. Psychotherapie und Sozialwissenschaft 2:74-94.

Tuckett D, Basile R, Birksted-Breen D, Böhm T, Denis P, Ferro A, Hintz H, Jemstedt A, Mariotti P, Schubert J (2008). Psychoanalysis comparable and incomparable. London: Routledge.

Vehviläinen S (2003). Preparing and delivering interpretations in psychoanalytic interaction. Text 23:573-606

Vehviläinen S (2008). Identifying and managing resistance in psychoanalytic interaction. In: Peräkylä A, Antaki C, Vehviläinen S, Leudar I, editors. Conversation analysis and psychotherapy, 120-38. Cambridge: Cambridge UP. 